K. Sunjog \& S. Kolarević \& K. Héberger \& Z. Gačić J. Knežević-Vukčević \& B. Vuković-Gačić M. Lenhardt, Comparison of comet assay parameters for estimation of genotoxicity by sum of ranking differences Analytical and Bioanalytical Chemistry, May 2013, Volume 405, Issue 14, pp 4879-4885

ISSN 1618-2642 Copyright Springer-Verlag Berlin Heidelberg 2013; published online: March 2013 DOI 10.1007/s00216-013-6909-y link: http://link.springer.com/article/10.1007/s00216-013-6909-y 


\title{
COMPARISON OF COMET ASSAY PARAMETERS FOR ESTIMATION OF GENOTOXICITY BY SUM OF RANKING DIFFERENCES
}

\author{
K. Sunjog' , S. Kolarević ${ }^{2}$, K. Héberger ${ }^{3}$, Z. Gačić ${ }^{1}$ J. Knežević-Vukčević ${ }^{2}$ \\ B. Vuković-Gačić ${ }^{2}$, M. Lenhardt ${ }^{1}$ \\ ${ }^{1}$ Department of Natural Resources and Environmental Sciences, Institute for Multidisciplinary Research, \\ Kneza Višeslava 1, University of Belgrade, Belgrade, Serbia \\ ${ }^{2}$ Center for genotoxicology and ecogenotoxicology, Chair of Microbiology, Faculty of Biology, Studenski Trg 16, \\ University of Belgrade, Belgrade, Serbia \\ ${ }^{3}$ Research Centre for Natural Sciences, Hungarian Academy of Sciences, \\ H-1025 Budapest, Pusztaszeri ut 59/67, Hungary
}

Corresponding author: Karolina Sunjog

E-mail: sunjogkarolina@imsi.rs

Telephone number-mob: +381638723805 


\begin{abstract}
Genotoxic potential of waters in six rivers and reservoirs from Serbia was monitored in different tissues of chub (Squalius cephalus L. 1758) with the alkaline comet assay. The comet assay, or a single cell gel electrophoresis, has a wide application as a simple and sensitive method for evaluating DNA damage in fish exposed to various xenobiotics in the aquatic environment. Three types of cells, erythrocytes, gills and liver cells were used for assessing of DNA damage. Images of randomly selected cells were analyzed with a fluorescence microscope Leica and image analysis by software (Comet Assay IV Image analysis system, PI, UK). Three parameters (tail length - 1, tail intensity - i and Olive tail moment - m) were analyzed on 1750 nuclei per cell type. The procedure for sum of ranking differences (SRD) was implemented to compare different types of cells and different parameters for estimation of DNA damage.

Regarding our nine different estimations of genotoxicity: tail length, intensity and moment in erythrocytes (rel, rei, rem), liver cells (rll, rli, rlm) and gill cells (rgl, rgi, rgm) SRD procedure has shown that the Olive tail moment and tail intensity are (almost) equally good parameters; the SRD value was lower for the tail moment and tail intensity than for tail length in case of all types of cells. The least reliable parameter was rel; close to the borderline case were rei, rll, and $\operatorname{rgl}(\sim 5 \%$ probability of random ranking).
\end{abstract}

Keywords: ecogenotoxicity, comet assay, comparison, parameters, ordering, fluorescence 


\section{Introduction}

The Comet Assay or single cell gel electrophoresis (SCGE) assay is a rapid, sensitive and relatively simple method for detecting DNA damage at the level of individual cells [1]. It combines the simplicity of biochemical techniques for detecting DNA single strand breaks (strand breaks and incomplete excision repair sites), alkali labile sites and cross-linking, with the single cell approach, typical for cytogenetic assays [2]. Comet assay has found its application in basic research as well as in applied sciences such as medicine, ecogenotoxicology, monitoring studies, etc. [3-7]. The comet assay is based on the ability of negatively charged loops/fragments of DNA to be drawn through an agarose gel in response to an electric field. The extent of DNA migration depends directly on the DNA damage present in the cells. DNA lesions consisting of strand breaks after treatment with alkali either alone or in combination with certain enzymes (e.g. endonucleases) increase DNA migration compared to those in concurrent controls [8]. The determination of the shape, size and amount of DNA within comets is a very important attribute of the assay if the damage is to be evaluated accurately.

In parallel with several technical and procedural evolutions to make the assay more robust, several approaches have also evolved to quantify the extent of damage more reliably, reproducibly and meaningfully. Such quantification includes both visual examinations (i.e., photographic, occulometer or non-specific image analysis systems) and the usage of commercially available (or public domain specific) image analysis software packages. Such specific software packages also facilitate statistical analyses, plotting and documentation of the data [2]. Besides that automated system provides an advantage over manual, not only for easier management, but also because of the lack of observer subjectivity.

As there are more parameters for the selection (tail moment, tail length, and tail intensity), it leads to controversy among researchers which is the most suitable parameter for assessing the damage of DNA. As sum of ranking differences (SRD) is entirely general, it is a suitable method to investigate which of the offered parameters is the most reliable to represent the damage of DNA molecules. SRD corresponds to the principle of parsimony; it provides an easy way to rank (e.g., techniques, models and methods) in a unique, justified way [9]. The method based on ranking is non-parametric and robust in the common sense. SRD values can be used to compare data originating from normal and definitely not normal distributions [10]. Tailings (outliers) do not significantly influence the ranking, so no distributional assumption is needed. 
The objective of this study was to find out which estimated parameters are the most reliable for the assessment of genotoxicity by sampling from sites with different antropogenic impacts, The Uvac River “Zlatar" reservoir (protected natural area), Reservoir Garasi with low and sites Bubanj Potok, Pestan, Beljanica, Kolubara with high degree of such impact. The data were obtained from comet assays performed on erythrocytes, gill and liver cells of chub (Squalius cephalus L.1758). The ranked parameters were tail length, tail intensity and Olive tail moment OTM [11].

\section{Material and methods}

\subsection{Field sampling}

Field sampling was conducted at four rivers (Bubanj potok, Kolubara, Pestan, Beljanica) and two reservoirs (Lakes Zlatar and Garasi) from Serbia. The Uvac River "Zlatar" reservoir (reference site) is protected natural area of great importance with very low antropogenic impact. Reservoir Garasi was chosen as the site with low anthropogenic impact as it is used as a drinking water intake. Rivers Pestan, Beljanica and Kolubara are polluted sites at Kolubara basin, which has rich deposits of lignite (brown coal), and hence the whole area is under intensive mining activity. Bubanj Potok is an example of municipal creek with impact of industrial waste. As far as we know there are no previous records of genotoxicity assessments of any kind of these rivers and reservoirs.

Total of 34 chub specimens was caught by electrofishing device ELEMAX SHX 2000 (SAWAFUJI) on rivers and by gill and trammel nets in reservoirs. Fish specimens were anesthetized with clove oil and samples of blood, gills and liver were collected, stored on ice and transferred to the laboratory in a dark cool box.

\subsection{Comet assay}

The alkaline comet assay procedure was performed under yellow light, in accordance with the method described by Singh et al. [1]. Microscopic slides were pre-coated with $0.5 \%$ NMP agarose and air dried for $24 \mathrm{~h}$. To form the second, supportive layer, $80 \mu \mathrm{l}$ of $1 \%$ NMP agarose was gently placed on the top of the $0.5 \%$ NMP layer and spread over the slide using a coverslip. The slide was placed on ice for $5 \mathrm{~min}$ to allow complete polymerization of the agarose. After the coverslips were removed, $30 \mu \mathrm{l}$ of cell pellet suspension, gently mixed with $70 \mu \mathrm{l}$ of $1 \% \mathrm{LMP}$ 
$\left(37^{\circ} \mathrm{C}\right)$ agarose, was pipetted on the supportive layer of $1 \%$ NMP agarose and covered with a coverslip. After keeping coverslips for $5 \mathrm{~min}$ on ice, they were removed and the slides were placed into freshly made cold lysis buffer $(2.5 \mathrm{M} \mathrm{NaCl}, 100 \mathrm{mM}$ EDTA, $10 \mathrm{mM}$ Tris, $1.5 \%$ Triton X-100, pH 10 and with 10\% Dimethyl sulfoxide for blood) for 1 hour. To allow DNA unwinding, slides were put into the electrophoresis chamber containing cold alkaline electrophoresis buffer (300 mM NaOH, $1 \mathrm{mM}$ EDTA, pH 13) for $20 \mathrm{~min}$. Electrophoresis was performed at $0.75 \mathrm{~V} / \mathrm{cm}$ at $4^{\circ} \mathrm{C}$ for $20 \mathrm{~min}$. After the electrophoresis, slides were placed into freshly made neutralizing buffer $(0.4$ M Tris, $\mathrm{pH}$ 7.5) for $15 \mathrm{~min}$. Staining was performed with $20 \mu \mathrm{l}$ per slide of $\operatorname{EtBr}(2 \mu \mathrm{g} \mathrm{mL}-1)$. The slides were examined with a fluorescence microscope (Leica, DMLS, Austria, $400 \times$ magnifications, $510-560 \mathrm{~nm}$ excitation filter, and $590 \mathrm{~nm}$ barrier filter). Microscopic images of comets were scored using Comet IV Computer Software (Perceptive Instruments, UK). Images of 50 cells were captured from each slide per sample and among the parameters available for analyses the tail length, tail intensity and OTM were chosen as parameters to assess the DNA damage (Figure 1).

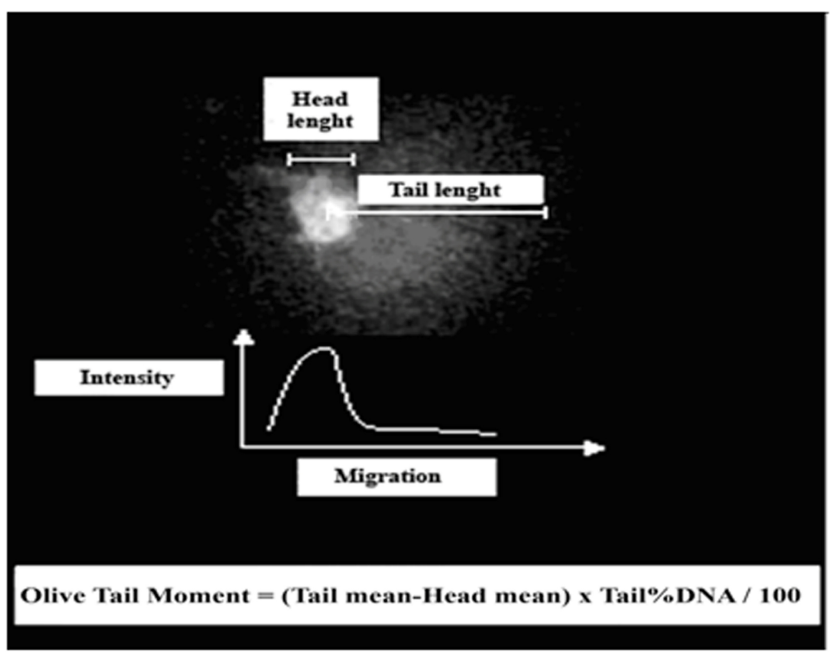

Fig. 1 Comet nucleoid showing a few basic parameters used for measurement (tail length, tail intensity, OTM)

\subsection{Sum of ranking differences (SRD) methodology}

SRD methodology has already been applied in various scientific disciplines in the past. It can be used for column selection in chromatography [9], for QSAR, QSPR and QSRR investigations [12-17], for testing performance for Raman spectra resolution [18] for grouping polarity measures $[19,20]$ for comparison of chemometric methods [21,22] for checking evaluation panels in food chemistry [23,24], for ranking polluted environmental sites [25], for 
comparing estimation methods of octanol-water partition coefficients $[10,26]$ for comparative evaluation of acidic dissociation constants [27] as well as for comparison of Elisa Veratox assay and liquid chromatography [28]. The SRD procedure is supervised in the sense that a reference (benchmark) ranking should be available. The data should be arranged in a matrix form. The objects (rows, in this case samples, 34 chub specimens) and the variables, nine different ways for estimations of genotoxicity with three types of evaluation: tail length, tail intensity and Olive tail moment, in three different cells: erythrocytes, liver, and gills cells. The notations contain three letters; the first " $r$ " indicates that rank numbers were analysed to avoid scaling problems, the second letter indicates the cell types, and the third letter shows the evaluation type: rel, rei, rem, rll, rli, rlm, rgl, rgi, rgm, respectively. The most apparent choice is to use the average of all estimations for genotoxicity as reference ranking (row average). The ranking by average values used to call consensus, since the errors cancel each other. The maximum likelihood principle will ensure that the most probable ranking will be provided by the average. However, the average is not necessarily a bias free solution, as the selection of models to be averaged is more or less arbitrary.

The absolute values of the differences between the average and individual rankings were calculated and summed for each evaluation method. The closer is the SRD value to zero (i.e. the closer is the ranking to the reference value), the "better" is the evaluation method in the sense that it is better suitable to replace all other methods. The proximity of SRD values shows that the methods behave similarly. Some groupings of evaluation methods can also be observed, whereas their distances show dissimilarity from the ordering point of view $[9,10]$.

Validation of the SRD procedure can be carried out by two ways (i) using simulated random numbers in conjunction with the theoretical distribution of the SRD values (generated by random numbers and corresponding to the number of specimens) called comparison of ranks with random numbers (CRRN) procedure; and (ii) using cross-validation (CV). The validation by CRRN procedure has been described earlier in detail in ref. [10]. Alternatively leave-manyout CV has been used following the literature recommendations [29]. Approximately 1/7th of the objects (specimens) were left out and the ranking was made on the remaining $6 / 7$ th number of objects. In such a way standard deviation can be calculated from the seven SRD values for each model. As the CV underestimates the real variance we may expect smaller CV variance than the true one. On the other hand if we assign the variance for the ranking to full number of objects, e.g. we assign (much) larger variance than the true one. The two effects compensate each other, hence less bias is expected. SRD corresponds to the principle of parsimony and provides an easy tool to rate the evaluation methods for genotoxicity. 


\section{Results}

During our investigation 34 specimens of chub were analyzed. Precisely from each specimen were analyzed three tissues: blood, liver and gills. As shown in Table 1, results are presented for each site per tissue and for all three parameters: tail length, tail intensity and Olive tail moment.

Regarding our nine different estimations of genotoxicity: tail length, intensity and moment in erythrocytes (rel, rei, rem), liver cells (rll, rli, rlm) and gills cells (rgl, rgi, rgm) SRD procedure showed that the tail moment and tail intensity are equally good parameters, more precisely that the SRD values were lower for the tail moment and tail intensity than for tail length (Figure 2).

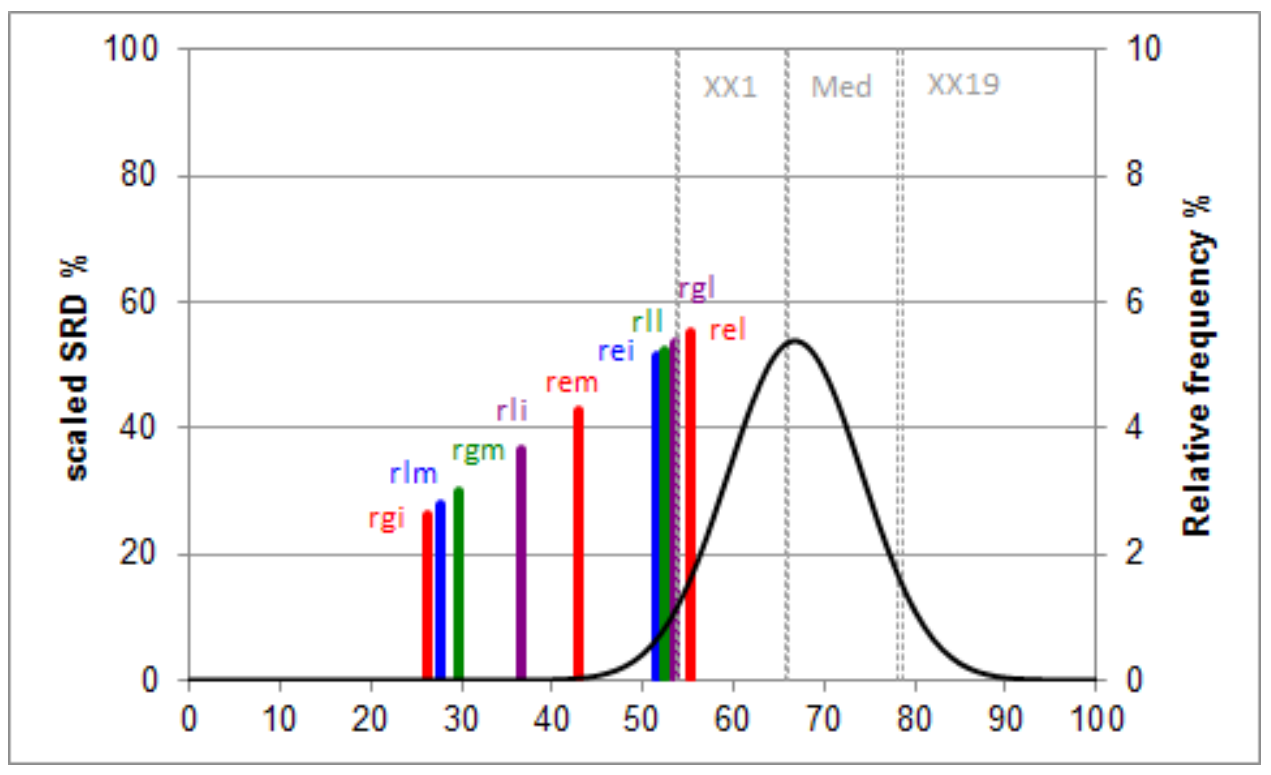

Fig. 2 SRD-CRRN test results of the data matrix given in Table 1. Y-axis, left-hand side, and X-axis-SRD-scaled values; Y-axis, right-hand side — relative frequencies (in percent) for the theoretical distribution function of random numbers

According to our results rel is the least reliable parameters. The overlapping is obvious: the ordering of-rel cannot be distinguished from the random ranking. Close to the borderline case were rei, rll and $\operatorname{rgl}(\sim 5 \%$ probability of random ranking). Figure 3 illustrates the uncertainty of SRD values calculated by seven folds cross validation. The figure naturally groups the similar ways for assessing genotoxicity. The last four ways (rll, rei, rgl, rel) are statistically not significant (at 5\% error level, according to sign test and Wilcoxon's matched pair test.) Similarly, rgi and rlm as well as rlm and rgm are not significantly different according to the mentioned level and tests above. 


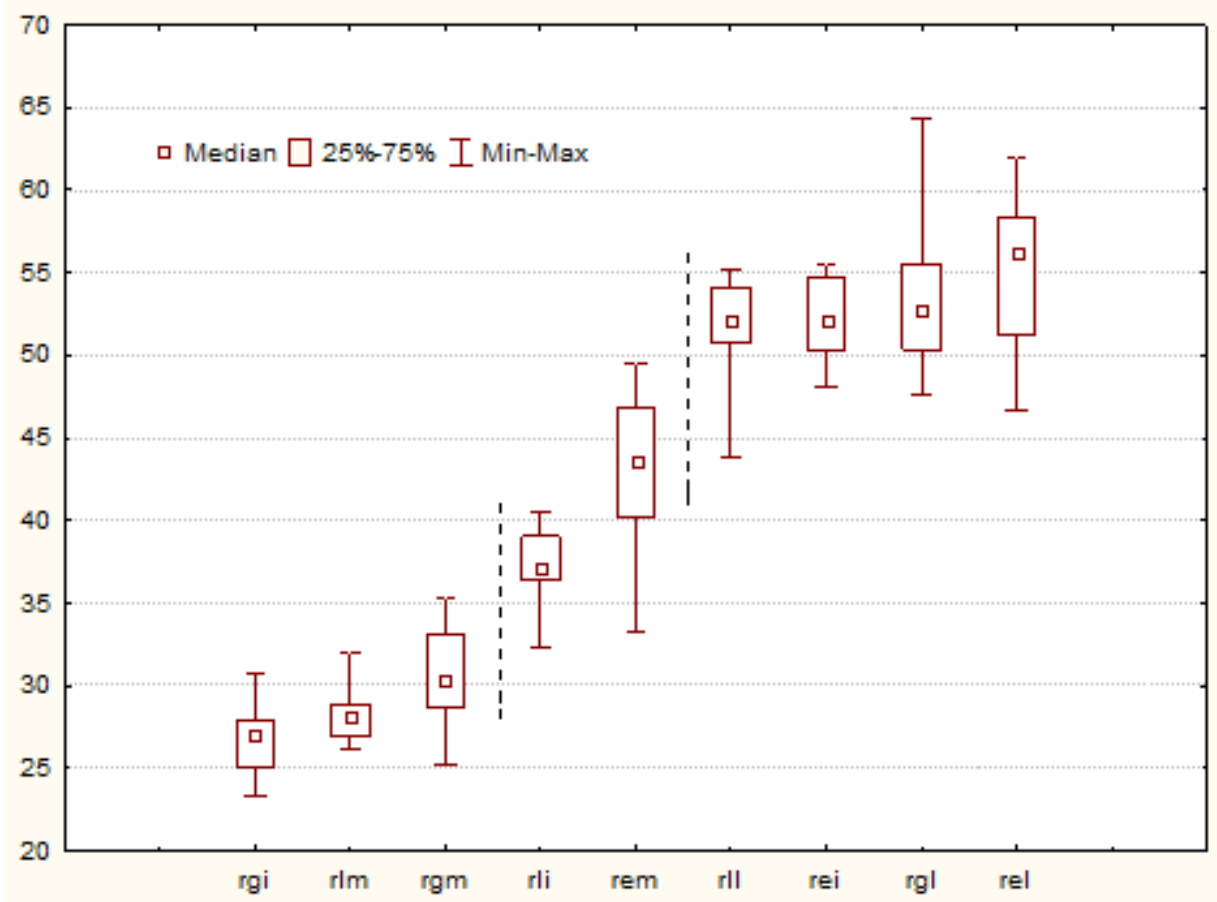

Fig. 3 Results of sevenfold cross validation: the uncertainties help to group the methods for determination of genotoxicity

\section{Discussion}

Three measures of DNA migration are commonly used: tail length, OTM, and $\%$ of the DNA in tail (tail intensity) [30-32]. Although OTM appeared to be the most statistically significant measurement [33], the inter-laboratory comparison of results seems to be difficult for this parameter [34]. OTM is calculated as a product of two factors: the percentage of DNA in the tail (tail intensity) and the distance between the intensity centroids (centers of gravity) of the head and the tail along the $\mathrm{X}$-axis of the comet (Figure 1). OTM calculation includes the distance between the intensity centroids of the head and the tail, which depends upon conditions of electrophoresis (e.g. electrophoresis time), and algorithms used to define the center of gravity of DNA distribution which vary among different software packages. Under these circumstances, it is advisable to use tail intensity for inter-laboratory comparisons [35-37]. When using derived measurements (e.g. tail moment), data on primary measurements (e.g. tail length and tail intensity) should also be presented in the analyses [8]. Tail length is considered unsatisfactory as a measure as it increases only while tails are first becoming established. Subsequently, the tail increases in intensity but not in length as the dose of damage increases. Tail length is also sensitive to the background or threshold setting of the 
image analysis program, as the end of the tail is defined by a certain excess of fluorescence over background [38]. Cells from different tissues or different species can differ substantially in tail length [35]. Still, tail length was, as a parameter, used in studies of genotoxicity in fish tissues [39-42]. Nevertheless, other parameters, especially, tail intensity and tail moment, were more extensively used in similar works [43-45]. Kumaravel and Jha [33] recommend that both OTM and \% tail intensity could be used for scientific purposes. Regarding the tissue selection for the analyses, three cell types were selected, following previous research, erythrocytes, liver and gills [31, 42, 46-48]. However, different tissues can accumulate pollutants to different degrees, depending on their biochemical characteristics [49]. Thus, the choice of tissues for the comet assay should also be related to the ability of the tissue to take up and metabolize xenobiotics. In fish, a tissue often chosen to perform the comet assay is the blood, because it is easy to collect and there is no need for cellular dissociation. In this work the choice of gill and liver cells, beside the red blood cells, was that the gills represent the first organ, which is in direct contact with water and, consequently, with the pollutants present in it, and the liver has great role in xenobiotic metabolism and accumulation [50]. According to our results, erythrocytes showed the smallest values comparing with other tissues. This may be due to the regular cycles of change of blood cells in the bloodstream, which indicates that blood could be used as a biomarker only for acute contaminations. Gills proved to be the most sensitive tissue for monitoring due to pronounced variation in values.

Regarding the tissue selection for further analysis, although gills proved to be the best biomarker, it is advisable to recommend all mentioned tissues, as each one is specific to the intensity and mode of stress response.

As for the parameters obtained using Comet IV Computer Software, it was shown that tail moment and tail intensity are the most suitable according to SRD method, which is correlated with the recommendations of scientists in the field mentioned above.

\section{Conclusion}

The comet assay has been used in biomonitoring and has proven to be a sensitive system for the study of environmental genotoxicity and could apply to a variety of different species, tissues and cells. Unfortunately, researchers use a lot of different parameters when representing results. With emergence of image analyzing systems the comet assay has several adopted parameters (tail length, intensity and moment). All three parameters have been 
employed so far among which tail intensity and moment were the most frequent ones, which we also recommend in accordance with our findings exploring SRD method.

\section{Acknowledgement}

This study represents a part of activities within the Project No. 173045, funded by the Ministry of Education and Science of the Republic of Serbia.

\section{References}

[1] Singh NP, McCoy MT, Tice RR, Schneider EL (1988) Exp Cell Res 175:184-191

[2] Kumaravel TS, Vilhar B, Faux SP, Jha AN (2009) Cell Biol Toxicol 25:53-64

[3] Frenzilli G, Nigro M, Lyons BP (2009) Mutation Res 681:80-92

[4] Meybodi AM, Mozdarani H (2009) Iranian Biomed J 13:1-8

[5] Kolarević S, Knežević-Vukčević J, Paunović M, Tomović J, Gačić Z, Vuković-Gačić B (2011) Arch Biol Sci 63(4):1209-1217

[6] Sunjog K, Gačić Z, Kolarević S, Višnjić-Jeftić Ž, Jarić I, Knežević-Vukčević J, Vuković-Gačić B, Lenhardt M (2012) The Scientific World Journal. Doi: 10.1100/2012/351074

[7] Bernardeschi M, Guidi P, Scarcelli V, Frenzilli G, Nigro M (2010) Anal Bioanal Chem 396:619-623

[8] Tice RR, Agurell E, Anderson D, Burlinson B, Hartmann A, Kobayashi H, Miyamae Y, Rojas E, Ryu JC, Sasaki YF (2000) Environ Molec Mutagenesis 35:206-21

[9] Héberger K (2010) Trends Anal Chem 29:101-109

[10] Héberger K, Kollár-Hunek K (2011), J Chemometr 25:151-158

[11] Olive PL, Banath JP, Durand RE (1990) Radiation Res 122:86-94

[12] Bolboaca SD, Jaentschi L (2010) Studia Univ Babes-Bolyai Chem 55:69-76

[13] Djakovic-Sekulic T, Mandic A, Trisovic N, Uscumlic G (2012) Current Computer Aided Drug Design 8:3-9

[14] Garkani-Nejad Z, Ahmadvand M (2011) Chromatographia 73:733-742

[15] Kar S, Roy K (2012) Chemosphere 87:339-355

[16] Liu X H, Ren YR, Zhou P, Shang ZC (2011) J Molec Struct 995:163-172

[17] Ojha PK, Roy K (2011) Chemometr Intell Lab Syst 109:146-161

[18] Vajna B, Farkas A, Pataki H, Zsigmond Z, Igricz T, Marosi G (2012) Anal Chim Acta 712: 45-55 
[19] Héberger K, Zenkevich IG (2010) J Chromatogr A, 1217:2895-2902

[20] Bielicka-Daszkiewicz K, Voelkel A, Pietrzyńska M, Héberger K (2010) J Chromatogr A 1217:5564-5570

[21] Gowen AA, Downey G, Esquerre C, O’Donnell CP (2011) J Chemomet 25:375-381

[22] Vajna B, Patyi G, Nagy Z, Bodis A, Farkas A, Marosi G, Raman J (2011) Spectr 42:1977-1986

[23] Kollár-Hunek K, Heszberger J, Kókai Z, Láng-Lázi M, Papp E (2008) J Chemometr 22: 218-226

[24] Sipos L, Kovács Z, Szöllösi D, Kókai Z, Dalmádi I, Fekete A (2011) J. Chemometr 25: 275-286

[25] Rocha MJ, Ferreira PC, Reis PA, Cruzeiro C, Rocha E (2011) J Chromatogr Sci 49:695-701

[26] Acanski MM, Vujic DN, Jovanovic-Santa S (2011) Chem Ind Chem Eng Quart 17:535-542

[27] Balogh GT, Tarcsay A, Keseru GM (2012) J Pharm Biomed Anal 67-68:63-70

[28] Tangni EK, Motte JC, Callebaut A, Chandelier A, De Schrijver M, Marnix L, Pussemier L (2011) Mycotoxin Res 27:105-113

[29] Hastie T, Tibshirani R, Friedman J (2009) The Elements of Statistical Learning: Data Mining, Inference, and Prediction, 2nd ed., Springer, New York

[30] Çok I, Ulutaş OK, Okuşluk O, Durmaz E, Demir N (2011) The Scientific World Journal 11:1455-1461

[31] Vincent-Hubert F, Arini A, Gourlay-Francé C (2011) Mutation Res 723:26-35

[32] Morin B, Filatreau J, Vicquelin L, Barjhoux I, Guinel S, Leray-Forget J, Cachot J (2011) Anal Bioanal Chem 399:2235-2242

[33] Kumaravel TS, Jha AN (2006) Mutation Res 605:7-16

[34] Rosenberger A, Rössler U, Hornhardt S, Sauter W, Bickeböller H, Wichmann HE, Gomolka M (2011) DNA Repair 10:322-337

[35] Collins AR, Oscoz AA, Brunborg G, Gaivao I, Giovannelli L, Kruszewski M, Smith CC, Štetina R (2008) Mutagenesis 23:143-151

[36] Speit G, Hartmann A (1999) Meth Mol Biol 113:203-212

[37] Burlinson B, Tice RR, Speit G, Agurell E, Brendler-Schwaab SY, Collins AR, Escobar P, Honma M, Kumaravel TS, Nakajima M, Sasaki YF, Thybaud V, Uno Y, Vasquez M, Hartmann A (2007) Mutation Res $627: 31-35$

[38] Collins AR (2004) Mol Biotechn 26:249-261

[39] Rajaguru P, Suba S, Palanivel M, Kalaiselvi K (2003) Environ Molec Mutagenesis 41:85-91 
[40] De Andrade VM, Da Silva J, Da Silva FR, Heuser VD, Dias JF, Yoneama ML, De Freitas TRO (2004) Environ Molec Mutagenesis 44:459-468

[41] Pandrangi R, Petras M, Ralph S, Vrzoc M (1995) Environ Molec Mutagenesis 26:345-356

[42] Alink GM, Quik JTK, Penders EJM, Spenkelink A, Rotteveel SGP, Maas JL, Hoogenboezem W (2007) Mutation Res 631:93-100

[43] Sharma S, Nagpure NS, Kumar R, Pandey S, Srivastava SK, Singh PJ, Mathur PK (2007) Arch Environ Contam Toxicol 53:617-623

[44] Wirzinger G, Weltje L, Gercken J, Sordyl H (2007) Mutation Res 628:19-30

[45] Pandeya AK, Nagpurea NS, Trivedib SP, Kumara R, Kushwahaa B (2011) Mutation Res 726:209-214

[46] Kopjar N, Mustafic P, Zanella D, Buj I, Caleta M, Marcic Z, Milic M, Dolenec Z, Mrakovcic M (2008) Folia Zool 57:120-130

[47] Cotelle S, Férard JF (1999) Environ Molec Mutagenesis 34:246-255

[48] Abd-Allaha GA, El-Fayoumib RI, Smith MJ, Heckmann RA, O'Neill KL (1999) Mutation Res 446:181-188

[49] Suicmez M, Kayim M, Koseoglu D, Hasdemir E (2006) Bull Environ Contam Toxicol 77:551-558

[50] Kilemade MF, Hartl MGJ, Sheehan D, Mothersill C, Van Pelt FNAM, O’Halloran J, O’Brien NM (2004) Environ Mol Mutagen 44:56-64 


\begin{tabular}{|c|c|c|c|c|c|c|c|c|c|c|}
\hline \multirow[b]{2}{*}{ Location } & \multirow{2}{*}{ specimen } & \multicolumn{3}{|c|}{ mean blood } & \multicolumn{3}{|c|}{ mean liver } & \multicolumn{3}{|c|}{ mean gills } \\
\hline & & 1 & $\mathrm{~m}$ & $\mathrm{i}$ & 1 & $\mathrm{~m}$ & $\mathrm{i}$ & 1 & $\mathrm{~m}$ & $\mathrm{i}$ \\
\hline \multirow{4}{*}{ Uvac, Lake Zlatar 17.05.2011. } & 1 & 13.8 & 0.42 & 4.89 & 22.66 & 0.53 & 3.62 & 15.3 & 0.35 & 3.9 \\
\hline & 2 & 13.24 & 0.26 & 3.46 & 15.74 & 0.52 & 6.15 & 17.24 & 0.35 & 3.28 \\
\hline & 3 & 14.96 & 0.26 & 3 & 18.04 & 0.43 & 4.81 & 16.84 & 0.31 & 3.3 \\
\hline & 4 & 13.66 & 0.28 & 3.94 & 18.18 & 0.51 & 5.46 & 12.54 & 0.52 & 7.96 \\
\hline \multirow{7}{*}{ Uvac, Lake Zlatar 24.10.2011. } & 1 & 17.64 & 0.39 & 3.76 & 27.38 & 0.53 & 3.45 & 21.04 & 0.49 & 3.96 \\
\hline & 2 & 18.96 & 0.32 & 2.51 & 24.2 & 0.31 & 2.9 & 25.82 & 0.73 & 6.43 \\
\hline & 3 & 15.42 & 0.32 & 2.78 & 22.48 & 0.69 & 4.88 & 22.96 & 0.48 & 4.37 \\
\hline & 4 & 17.02 & 0.44 & 3.17 & 21.74 & 0.3 & 4.3 & 25.06 & 0.36 & 2.44 \\
\hline & 5 & 16.36 & 0.3 & 4.68 & 16 & 0.53 & 3.22 & 17.22 & 0.36 & 3.65 \\
\hline & 6 & 17.82 & 0.27 & 3 & 28.38 & 0.63 & 4.49 & 18.36 & 0.58 & 4.02 \\
\hline & 7 & 18.04 & 0.29 & 2.77 & 17.2 & 0.41 & 2.91 & 22.6 & 0.92 & 5.49 \\
\hline \multirow{4}{*}{ Bubanj potok 29.06.2011. } & 1 & 12.12 & 0.52 & 7.75 & 18.32 & 0.72 & 6.54 & 21.38 & 0.99 & 7.59 \\
\hline & 2 & 13.8 & 0.41 & 4.52 & 18.16 & 0.68 & 5.63 & 36.86 & 1.46 & 7.21 \\
\hline & 3 & 14.3 & 0.5 & 6.17 & 20.18 & 0.53 & 4.3 & 25.2 & 0.93 & 6.62 \\
\hline & 4 & 14.94 & 0.47 & 5.3 & 21.1 & 0.82 & 6.14 & 18.88 & 0.74 & 6.57 \\
\hline \multirow{4}{*}{ Kolubara 1.07.2011. } & 1 & 15.2 & 0.56 & 5.83 & 24.7 & 0.51 & 3.35 & 17.58 & 0.58 & 5.22 \\
\hline & 2 & 14.92 & 0.46 & 5.36 & 21.22 & 0.46 & 3.66 & 23.08 & 0.47 & 3.77 \\
\hline & 3 & 13.88 & 0.42 & 6.03 & 17.14 & 0.74 & 7.19 & 18.88 & 0.5 & 4.91 \\
\hline & 4 & 14.5 & 0.53 & 7.63 & 16.6 & 0.35 & 3.46 & 16.88 & 0.58 & 6.29 \\
\hline \multirow{4}{*}{ Pestan 30.06.2011. } & 1 & 15.66 & 0.39 & 3.96 & 21.96 & 0.93 & 6.89 & 17.42 & 1.01 & 9.55 \\
\hline & 2 & 13.4 & 0.59 & 7.09 & 22.32 & 0.87 & 6.11 & 21.04 & 1.27 & 9.92 \\
\hline & 3 & 18.62 & 0.55 & 4.43 & 26.9 & 1.24 & 7.3 & 21.14 & 1.3 & 9.92 \\
\hline & 4 & 13.4 & 0.65 & 10 & 15.74 & 0.82 & 7.85 & 24.38 & 1.99 & 13.54 \\
\hline \multirow{3}{*}{ Pestan 14.10.2011. } & 1 & 17.44 & 0.51 & 5.02 & 27.42 & 1.12 & 7.15 & 15.7 & 0.77 & 8.91 \\
\hline & 2 & 18.38 & 0.41 & 3.38 & 18.78 & 0.67 & 5.26 & 26.42 & 1.45 & 9.73 \\
\hline & 3 & 16.26 & 0.39 & 3.99 & 24.98 & 1.06 & 7.43 & 17.3 & 0.63 & 6.27 \\
\hline \multirow{3}{*}{ Beljanica 14.10.2011. } & 1 & 14.16 & 0.45 & 5.61 & 21.5 & 0.6 & 4.55 & 23.64 & 1.35 & 9.44 \\
\hline & 2 & 16.28 & 0.43 & 4.72 & 16.32 & 0.64 & 6.28 & 18.38 & 0.77 & 6.79 \\
\hline & 3 & 17.96 & 0.55 & 4.93 & 28.94 & 1.47 & 9.1 & 18.16 & 1.1 & 11.61 \\
\hline \multirow{5}{*}{ Garasi 4.11.2011. } & 1 & 15.12 & 0.19 & 2.03 & 18.44 & 1.07 & 8.87 & 21.4 & 0.83 & 6.42 \\
\hline & 2 & 15.74 & 0.43 & 4.07 & 17.08 & 0.63 & 6.13 & 20.5 & 1.09 & 8.37 \\
\hline & 3 & 19.22 & 0.56 & 4.92 & 21 & 0.95 & 7.21 & 19.18 & 0.55 & 4.8 \\
\hline & 4 & 17.84 & 0.31 & 2.72 & 20.5 & 0.78 & 6.6 & 19.4 & 0.77 & 6.65 \\
\hline & 5 & 14.84 & 0.3 & 3.27 & 22.76 & 0.67 & 5.02 & 18.94 & 0.91 & 7.74 \\
\hline
\end{tabular}

Table 1 Comet assay results represent three parameters (tail length -1 , tail intensity $-i$, tail moment $-m$ ) for three tissues (blood, liver, gills) of chub sampled at four rivers (Bubanj Potok, Kolubara, Pestan, Beljanica) and two reservoirs (Lakes Zlatar and Garasi) during 2011 